\title{
Examining Students' Perceptions of E-Learning in a Women-Only Environment
}

\author{
http://dx.doi.org/10.3991/ijac.v8i4.4835 \\ Karin Sixl-Daniell ${ }^{1}$ and Amy Wong ${ }^{2}$ \\ ${ }^{1}$ MCI Management Center Innsbruck, Innsbruck, Austria \\ ${ }^{2}$ GlobalNxt University, Kuala Lumpur, Malaysia
}

\begin{abstract}
In terms of achieving growth and profitability, women play an important role in public and private organizations. Despite the increase of women in the workforce, they continue to be underrepresented in managerial positions. Appropriate initiatives need to be implemented in an organization to manage and retain women talent. Online courses catered specifically to women can provide women professionals with relevant development opportunities throughout their career, as these women-only programs allow women to freely discuss their particular issues and concerns in a supportive and safe climate. Apart from being flexible and cost effective, these online women-only courses provide an optimal learning environment for women to share and analyze the unique strengths, weaknesses, challenges, and opportunities facing women in the workplace. Yet, several questions exist concerning the design and delivery of such online courses, particularly from the student's perspective.
\end{abstract}

In this study, students' perceptions of e-learning in a women-only environment are examined. An exploratory study of female students enrolled in an Executive Certificate of Leadership for Women, which is a customized online program facilitated by international PhD qualified women faculty, is conducted to understand students' perceptions of the various attributes of a women-only online learning course.

Index Terms-E-Learning, Executive Education, Leadership, Women

\section{INTRODUCTION TO CORPORATE E-LEARNING}

Over the past decades, the number of women assuming corporate leadership roles has risen in most parts of the world as women play an increasingly important role in public and private organizations. In 2013, women held $24 \%$ of senior management roles worldwide with numbers ranging from $21 \%$ in North America to $32 \%$ in ASEAN countries. In China and Poland, senior management positions were held by $51 \%$ and $48 \%$ of women respectively [1]. Despite these figures, women still face a gender gap in senior leadership positions, even though women outnumber men in college graduation rates and form the majority of entry-level employees [2].

A 2008 McKinsey study of top European companies found that greater gender diversity resulted in higher than average stock performance [3]. A recent study found that companies that perform best financially have the highest number of women in leadership roles [4]. Another study found that women are less likely to compromise ethics in leadership positions than their male counterparts, leading to ethically sounder decisions in a corporate environment [5].
However, while the number of women in managerial positions has grown, women continue to be underrepresented in managerial positions, with this gender gap being most evident at the senior management and executive levels. Research cites reasons such as the absence of training and professional development opportunities for women globally [6].

In 2012, only one-sixth of board seats in Fortune 500 companies were held by women: $19 \%$ of nominating/governance chairs, $15.9 \%$ of audit committee members, $11.3 \%$ of compensation committee members, $8.4 \%$ of lead directors, and $3.3 \%$ of board chairs [7]. In 2014, women held only $4.6 \%$ of CEO positions at S\&P 500 companies [8], while only $5 \%$ of Fortune 500 companies remained with all male boards [9]. This tendency persists although a 2010 study of Fortune 500 firms found that those with more women in senior positions were more profitable than median companies in their industries [10].

Given the above findings, it is imperative that organizations increase the percentage of women within the company, in particular in mid to top-level positions, as this would in turn increase the likelihood of sustaining gender diversity at every level of the organization [11]. Such an approach can give rise to more female role models within the organization, which may result in (more) female mentors. This may enable female employees at the beginning of their careers to clearly see a path for career progression which involves the handling of multiple life commitments.

Not only does the percentage of women in mid to toplevel positions need to be increased, these women also need to be retained in the organization in order to reap the full benefits of their involvement and commitment. As such, corporate educational activities and appropriate initiatives that are beneficial to an organization can accomplish this.

This paper discusses the perceptions of women leaders in a corporate e-learning initiative and presents some findings of an online executive education course created specifically for women managers to foster their leadership skills. The paper examines the implications of the findings and concludes with possible future research.

\section{WOMEN LEADERS}

A study by Adler on leadership style found that a woman's style of leadership appears to be more towards a transformational style, relying more on interpersonal skills [12]. These styles are more relational-oriented, nurturing, caring, and compassionate, as most researchers credit women with some or all of the following qualities: empathy, helpfulness, caring, and nurturance; interpersonal 
PAPER

EXAMINING StUdENTS' PERCEPTIONS OF E-LEARNING IN A WOMEN-ONLY ENVIRONMENT

sensitivity, attentiveness to and acceptance of others, responsiveness to their needs and motivations; an orientation toward the collective interest and toward integrative goals such as group cohesiveness and stability; a preference for open, egalitarian, and cooperative relationships, rather than hierarchical ones; and an interest in actualizing values and relationships of great importance to community [13]. The study also indicated that global business women gain access to new clients, suppliers, and government officials more easily, receive more time when meeting with international contacts, and are more frequently remembered. These unique qualities are important contributors to overall organizational success.

Special attention should be given to the retention of women talent within an organization as the multiple life commitments (i.e., child bearing years, family responsibilities such as caring for young children and elderly parents) women face often require a different approach for women than for men when it comes to talent retention. Women should have access to relevant development opportunities throughout their careers [14]. While at the beginning of their careers, women should be provided with opportunities to experiment and practise their skill sets and abilities in a supportive environment [15], it becomes more and more important to foster and widen the skill sets throughout their careers via appropriate corporate educational initiatives. Women-only development programs can be used as a talent retention tool, as many women can freely discuss particular issues and concerns in a supportive and safe climate such as a like-minded group.

According to studies conducted in the UK, women tend to feel more at ease in single sex institutions when it comes to subjects such as science and mathematics. The studies reported that gender stereotyping stands out more in post high school in a co-educational environment rather than in a single sex environment $\lceil 16,17\rceil$. It has also been observed that in single-sex settings with a stronger element of collaboration, girls tend to have an easier time at learning, with the learning experience becoming more meaningful. This reinforces the importance of collaborative learning in single sex environment [18] and emphasizes the value of women-only developmental programs. Further, there is considerable evidence that appropriate women-only education and training is of critical importance to women's career development and progression [19]. Hence, women-only programs could be an effective way of enhancing a participant's skill set.

\section{CORPORATE EDUCATION INITIATIVES IN LEADERSHIP FOR WOMEN}

Organizations should pay special attention to the management of women talent as it is critical that businesses take responsibility for creating a culture that values diversity and developing its women talent pipeline at all levels of management. Organizational culture can play an important role in reducing barriers to women's career advancement. A female mentor or role model can contribute to the career development and progression of women professionals through modeling workplace behavior and skills such as time management, stress management, teamwork, and communication. Furthermore, organizations can implement initiatives such as the development of career advancement plans in consultation with senior management, and provide opportunities for continuous, life-long learning [20].
Women only training and development programs provide opportunities for women to develop self-awareness, undertake challenging assignments, improve their selfconfidence, develop leadership skills, learn strategies for balancing work and personal life, and build strong support networks [21, 22]. Such benefits have been identified as important elements in ensuring that women progress to senior positions in organizations and onto boards.

Given the above training and development needs, some of the emerging courses women professionals should look out for include courses in the areas of e.g. leadership, mentoring, coaching, change management, strategy, and others.

\section{PERCEPTIONS OF E-LEARNING IN CORPORATE EDUCATION FOR WOMEN}

Given the multiple life commitment issues many women in managerial positions face, online courses catered specifically to women may provide women professionals with relevant development opportunities throughout their career.

Apart from being flexible, time as well as cost effective, available 24/7, location independent and fast to update, these online women-only courses provide an optimal learning environment for women to share and analyze the unique strengths, weaknesses, challenges, and opportunities facing women in the workplace without the women having to travel for these courses. Yet, several questions exist concerning the design and delivery of such online courses, particularly from the student's perspective.

This study examines students' perceptions of e-learning in a women-only environment. An online survey was conducted to understand students' perceptions of the various attributes of a women-only online learning course. These students were enrolled in an Executive Certificate of Leadership for Women at GlobalNxt University, which is a customized online program compiled and facilitated by international $\mathrm{PhD}$ qualified women faculty. GlobalNxt University (formerly U21Global or Universitas21Global) delivers degree programs via a unique online global classroom pedagogy. Through a state-of-the-art online learning platform, the university offers students highly interactive learning anytime and from anywhere. The university's globally diverse student population is represented by over 72 different countries. In addition, through close industry partnerships, the university has talent development programs with over 100 multinational companies.

The Executive Certificate of Leadership for Women is a 22-weeks online program and consists of one week of student orientation, 18 weeks covering six modules, two weeks for a final reflective team project and one week for grading and moderation. It is aimed at delivering highly interactive and deep learning that is inclusive, meaningful, and authentic for its participants. The program provides a sound understanding of business leadership fundamentals that equip women executives with the ability to manage innovation and value creation for all stakeholders. The program is flexible and cost effective, as it brings international women faculty and students into the specially designed online community, greatly reducing the need for women executives to have to leave their work venues and families to travel to participate in this program.

As the program was designed by women for women, it acknowledges the specific issues that women face such as 
PAPER

EXAMINING StUdENTS' PERCEPTIONS OF E-LEARNING IN A WOMEN-ONLY ENVIRONMENT

juggling family and work responsibilities and managing dual-career relationships associated with pursuing careers at the expense of family. The program comprises six out of the following modules: People Leadership, Ethical Decision Making, Business Communication, Entrepreneurial Thinking, Managing Change, Corporate Social Responsibility, and Strategic Management for Innovative Businesses as well as a final reflective project. Each module is delivered over the course of three weeks in a mix of asynchronous and as well as synchronous elements, consisting of ongoing online asynchronous discussions and two webinars. Participants need to be prepared to spend a minimum of seven hours per week of study time for the online component and two hours for each webinar session conducted by the female professor.

\section{METHOD}

The data for this exploratory study was collected from female students who were enrolled in the online executive education program for women executives in 2014. An online post-course survey was administered. The response rate was $59 \%$ percent. The sample consisted of 17 female middle managers with an average working experience of 7.5 years. All the variables used in this study were assessed using five-point Likert scales, with 1 representing "strongly disagree" and 5 representing "strongly agree". Open ended questions were also elicited, such as what they liked most/least about the program and any improvements/suggestions that can be made.

\section{FINDINGS}

Results of the exploratory study indicated that the majority of students agreed or strongly agreed that the women-only environment was conducive to learning (82\%). The students also agreed or strongly agreed that the women only environment was intellectually challenging (76\%).

As role models, the female professors provided practical examples to integrate the theoretical aspects of the program, thus reinforcing learning at the end of each module. The majority of participants stated that they feel that the female professors in the program understood their needs better than male professors would. Around half of the students mentioned that they felt more at ease in a female-only class. Other comments include "the course content and discussions were good. (The) women-only environment made us understand the problems faced by women and triggered open discussions" and "this course was great learning for me. I enjoyed every aspect of the course and I was always excited to learn and share more. The professors were actually invoking and inducing that extra motivation and excitement in me".

Participants also highlighted that the customized content $(88 \%)$ and assignments/projects $(88 \%)$ were highly relevant to their work environments. This is reinforced by the following comments: "The e-content was very informative and I learnt many new concepts. The case studies perfectly complemented the e-content" and "I like all modules as they are valuable and I gain lot of inputs from this course work".

All participants expressed their satisfaction with the program. Analysis of the open ended feedback showed a high degree of satisfaction among the students. One participant remarked "I liked the course very much. It is relevant and strongly recommended." Another student men- tioned "being a part of this program had an immediate impact on my work as it gave me access to so many new resources. I wasn't sure what to expect, but the program quickly provided me with new ways of thinking, a new set of management tools and terrific people connections. What I really liked is that the program is practical and easy to apply. The course content, faculty and learning environment were creative, innovative and collaborative. I left [the program] energized, connected and engaged. Definitely worth the investment!". Further students' feedback included "I enjoyed the program a lot from the beginning to the end; course contents were rich, teachers were always helpful and doubts were always answered", as well as "The content on the e-module, the rich sharing from my experienced friends and the probing and insightful inputs from the professor has made the entire learning experience very meaningful." and "I liked the format, the sequential learning was excellent. The interactive study was very enriching as was the guidance by the professors. The discussion boards were a very good learning platform." These comments show how valuable such corporate initiatives aimed at women can be.

The vast majority of the participants felt that the peer interaction in the program contributed to their learning. It appears that the opportunity for interacting with other women (i.e., peers, faculty, and industry guest speakers) from a broad range of backgrounds has enhanced both learning and personal development. In addition to the program content, the participants experienced improved self-confidence due to the fact that they had been invited to join the program. This was also observed in another study [23] and is a strong indicator that their contributions are valued within the organization, that their potential is recognized, and that the organization is willing to invest in their ongoing development. It also signaled a greater likelihood of them moving into more senior positions and thus created higher motivation and positive career aspirations among the participants.

As seen from the findings, students' perceptions of the Executive Certificate of Leadership for Women are positive and the program has met the training and development needs of the participants.

\section{LIMITATIONS AND FUTURE RESEARCH}

The data for this exploratory study is limited to a batch of 17 students from four countries, namely Singapore, India, USA, and Canada). Future research should extend the scope of data collection to include larger samples of students from a variety of organizations, as well as a variety of geographies and industries to further investigate these findings. Specifically, several research questions emerge. Does the country of origin of the participants play a role in determining the perceived effectiveness of online executive education? Does the organization type, size, industry or culture play a role in determining the perceived effectiveness of online executive education? How can organizations design and deliver effective online executive education programs for female managers? Do such programs have a long term effect on career development? What effect does such a program have on the promotion, and subsequently career advancement of the participants? Does the salary difference between the two genders narrow as a result of such programs? These questions may provide interesting topics for further study. 
PAPER

EXAMINING Students' PERCEPTIONS OF E-LEARning IN A WOMEN-ONLy ENVIRONMENT

\section{REFERENCES}

[1] Catalyst: Catalyst Census: Fortune 500 Women Board Directors. 2013. http://www.catalyst.org/knowledge/2013-catalyst-censusfortune-500-women-board-directors

[2] Yee L.: Fostering Women Leaders: A fitness test for your top team. The McKinsey Quarterly, January 2015

[3] Desvaux, G., Devillard-Hoellinger, S. and Meaney, M.C.: A business case for women. The McKinsey Quarterly, September 2008 .

[4] DDI: Ready-Now Leaders: Meeting Tomorrow's Business Challenges. Global Leadership Forecast. 2015. http://www.ddiworld.com/DDI/media/trend-research/globalleadership-forecast-2014-2015 tr ddi.pdf?ext=.pdf

[5] Kennedy J. and Kray L. "Who is Willing to Sacrifice Sacred Values for Money and Social Status? Gender Differences in Reactions to Taboo Trade-offs." IRLE Working Paper No. 124-12. 2012. http://irle.berkeley.edu/workingpapers/124-12.pdf

[6] Davis, P. J.: The global training deficit: The scarcity of formal and informal professional development opportunities for women entrepreneurs. Industrial and Commercial Training, 44(1), 2012, pp. 19-25. http://dx.doi.org/10.1108/00197851211193381

[7] Catalyst: 2013 Catalyst Census: Fortune 500 Women Board Directors. 2013. http://www.catalyst.org/knowledge/2013catalyst-census-fortune-500-women-board-directors

[8] Catalyst: Women CEOs of the S\&P 500. 2015. http://www.catalyst.org/knowledge/women-ceos-sp-500

[9] Fairchild C.: The 23 Fortune 500 companies with all-male boards. In: $\quad$ Fortune, $16 \quad$ January 2015 http://fortune.com/2015/01/16/fortune-500-companies-with-allmale-boards/

[10] Wolfe, L.: A decade of women CEOs at FORTUNE 500 companies,

2010 http://womeninbusiness.about.com/od/womeninbusinessnew1/a/de cade-women-ceos.htm

[11] Taneja, S., Pryor, M. G. \& Oyler, J.: Empowerment and gender equality: The retention and promotion of women in the workforce. The Journal of Business Diversity, 12(3), 2012, pp. 43-53.

[12] Rosener J.: Ways women lead. Harvard Business Review November-December 1990, pp. 119-25

[13] Adler, N. J.. Global leadership: Women leaders. Management International Review, 37(1), 1997, pp. 171-196. http://dx.doi.org/10.1007/978-3-322-90987-9 10

[14] Knight, J.: Top women leaders. Training Journal,2012, pp. 54-58.
[15] Dent, F. \& Holton, V.: How women can navigate to become global leaders. Global Focus: The EFMD Business Magazine, 6(2), 2012, pp. 40-43.

[16] Sullivan, A., Joshi, H. \& Leonard, D.: Single-sex schooling and academic attainment at school and through the life course. American Educational Research Journal, 47(1), 2010, pp. 6-36. http://dx.doi.org/10.3102/0002831209350106

[17] Sullivan, A., Joshi, H. \& Leonard, D.: Single-sex schooling and labour market outcomes. Oxford Review of Education, 37(3), 2011, pp. 311-322. http://dx.doi.org/10.1080/03054985.2010. 545194

[18] Hughes T.: The Advantages of Single Sex Education. National Forum of Educational Administration and Supervision Journal. Vol. 23, Number 2, 2006-2007

[19] Clarke, M.. Advancing women's careers through leadership development programs. Employee Relations, 33 (5), 2006, pp. 498515. http://dx.doi.org/10.1108/01425451111153871

[20] Arifeen, S. R.: The development of managerial women: An exploratory comparison of Malaysia and Pakistan. IUP Journal of Management Research, 9(2), 2010, pp. 21-36.

[21] O'Neil, D.A. \& Bilimoria, D.: Women's career development phases: idealism, endurance, and reinvention. Career Development International, 10(3), 2005, pp. 168-89. http://dx.doi.org/10.1108/ 13620430510598300

[22] Weyer, B.: Twenty years later: explaining the persistence of the glass ceiling for women leaders. Women in Management Review, 22(6), 2007, pp. 482-96. http://dx.doi.org/10.1108/096494207 10778718

[23] Wong A., Sixl-Daniell K.: Online Executive Education for Women Leaders. Oxford Journal. An International Journal of Business and Economics, 9(2), 2014, pp. 215-221

\section{AUTHORS}

Karin Sixl-Daniell is with MCI Management Center Innsbruck, Innsbruck, Austria (e-mail: karin.sixl@ mci.edu).

Amy Wong is with GlobalNxt University, Kuala Lumpur, Malaysia (e-mail: amy.wong@globalnxt.edu.my).

This article is an extended and modified version of a paper presented at the the International Conference on E-learning in the Workplace 2015 (ICELW'15), held in June 2015, at Columbia University in New York, NY, USA. Manuscript received 11 March 2015. Published as resubmitted by the authors 30 November 2015 